\title{
Removal of Uranium from Aqueous Solutions using Ammonium-modified Zeolite
}

\author{
Elisée N. Bakatula, Alseno K. Mosai and Hlanganani Tutu* \\ Molecular Sciences Institute, School of Chemistry, University of the Witwatersrand, Private Bag X3, WITS, 2050, South Africa.
}

Received 24 February 2015, revised 22 April 2015, accepted 23 April 2015.

\begin{abstract}
Batch experiments were conducted to study the effects of contact time, $\mathrm{pH}$ (3 to 8), initial concentration, presence of carbonate, sulphate, and competing ions $\left(\mathrm{Fe}^{3+}, \mathrm{Ca}^{2+}, \mathrm{Sr}^{2+}, \mathrm{Mg}^{2+}\right)$ on the adsorption of U(VI) on ammonium-modified zeolite (AMZ). The structural features of the modified zeolite were assessed by Fourier Transform Infra Red Spectroscopy (FTIR) while the metal content was determined by Inductively Coupled Plasma Optical Emission Specroscopy (ICP-OES). The removal of uranium was effective and maximal under acidic conditions ( $\mathrm{pH} 3$ to 5). The kinetics of adsorption of U-nitrate and U-sulphate on AMZ were described by the pseudo-second-order model $\left(R^{2} \geq 0.9820\right)$. In the presence of $\mathrm{SO}_{4}{ }^{2-}$ and $\mathrm{CO}_{3}{ }^{2-}$, a significant reduction of $67.88 \%$ and $71.63 \%$, respectively, in uranium uptake was observed. The distribution coefficient, $K_{D}\left(\mathrm{~L} \mathrm{~g}^{-1}\right)$, was in the order of: $U$-nitrate (1.116) > U-sulphate (0.029) > U-carbonate (0.019), suggesting that AMZ had a high affinity for U-nitrate. The presence of Fe ${ }^{3+}$ enhanced the removal of $U(V I)$ from $U$-nitrate, $U$-sulphate and $U$-carbonate by $20.18 \%, 72.48 \%$ and $82.43 \%$, respectively, while the presence of $\mathrm{Ca}^{2+}, \mathrm{Mg}^{2+}$ and $\mathrm{Sr}^{2+}$ reduced the removal to $19.57 \%, 31.60 \%$ and $23.65 \%$, respectively. AMZ is an effective adsorbent for uranium removal from aqueous solutions dominated by nitrate, carbonate and sulphate.
\end{abstract}

KEYWORDS

Adsorption, zeolite-ammonium, uranyl, carbonate, sulphate, nitrate, aqueous solutions.

\section{Introduction}

Gold, platinum, diamond and coal are amongst several minerals that are commonly mined in South Africa. A large proportion of gold (98\%) in South Africa is mined in the Witwatersrand goldfields. ${ }^{1}$ When gold is extracted, large amounts of rocks are crushed and processed, producing large quantities of waste in the process. The improper management of this waste has led to many environmental concerns such as erosion and the production of acid mine drainage. ${ }^{2}$ Uranium is one of the metals of concern occurring in significant amounts in gold mining waste. The Witwatersrand gold ores have significant concentrations of uranium between 30 and 2000 ppm since uranium occurs as an accessory mineral in the gold ores. ${ }^{3}$ The discharges of uranium and associated radionuclides from waste and tailing dumps in abandoned uranium mining and processing sites pose contamination risks to surface and groundwater. ${ }^{4,5}$

The toxic effects due to uranium exposure are based on its chemical and radioactive characteristics. The presence of high levels of uranium (U) compounds in the human body has been reported to affect renal functions, leading to kidney failure. ${ }^{6}$ Uranium is also associated with toxicity to crops, livestock as well as aquatic organisms. ${ }^{7}$ The maximum uranium level in drinking water recommended by the World Health Organization and the South African Bureau of Standards is $15 \mu \mathrm{g} \mathrm{L} \mathrm{L}^{-1,8,9}$ the maximum contaminant level (MCL) set by the USEPA for drinking water standard is $20 \mu \mathrm{g} \mathrm{L}^{-1}$. $^{10}$

Under oxidizing geochemical conditions, the most stable oxidation state of uranium is $\mathrm{U}(\mathrm{VI})^{11}$ which exists in acidic aqueous solution as the linear uranyl ion, $\mathrm{UO}_{2}{ }^{2+}$. At higher $\mathrm{pH}$, the uranyl ion hydrolyzes extensively, forming monomers $\left[\mathrm{UO}_{2}(\mathrm{OH})^{+}\right]$and dimers $\left[\left(\mathrm{UO}_{2}\right)_{2}(\mathrm{OH})_{2}{ }^{2+}\right]$. Both the migration and retardation of uranyl ions in geological environments are

* To whom correspondence should be addressed. E-mail: hlanganani.tutu@ wits.ac.za controlled primarily by the sorption of these toxic species to mineral surfaces. ${ }^{12}$ Hence, predicting the future fate and transport of uranyl in contaminated sites requires an understanding of the factors affecting their sorption onto minerals. Many parameters govern uranyl sorption behaviour onto minerals; these include: $\mathrm{pH}$, initial uranium concentration, presence and absence of complexing ligands such as sulphates, carbonates, phosphates, nitrates, chlorides and organic acids. Uranyl has been reported to be strongly adsorbed onto many soil constituents including clay minerals such as zeolites under appropriate chemical conditions. Such materials can be used for uranium (VI) remediation of aqueous solutions. ${ }^{13-15}$

Adsorbents such as natural zeolite are cost-effective for the removal of uranium, although their modified versions tend to perform better. ${ }^{13-14}$ It should be noted that at times this modification is not deliberate, but may be a result of natural processes in environments where the adsorbents are deployed. For instance, ammonium is one of the dominant components in aqueous systems and may influence the surface properties of such adsorbents. It is on this premise that this study was conducted. It was aimed at assessing the capability of ammonium-modified zeolite (AMZ) to adsorb uranium occurring in different aqueous systems, e.g. nitrate-, sulphate- and carbonate-dominated systems. The latter two of these systems would typically be acid mine drainage (AMD)-impacted and lime-neutralized systems while the former would be expected to dominate in most natural water systems. The adsorption behaviour of uranium on AMZ was studied under various conditions, namely: contact time, $\mathrm{pH}$, uranium initial concentration, solid/1iquid $(\mathrm{S} / \mathrm{L})$ ratio and the presence of $\mathrm{CO}_{3}^{2-}, \mathrm{SO}_{4}^{2-}, \mathrm{Sr}^{2+}, \mathrm{Mg}^{2+}, \mathrm{Ca}^{2+}$ and $\mathrm{Fe}^{3+}$. Desorption of uranium from the AMZ was also studied to assess the potential re-use of the adsorbent. 


\section{Materials and Methods}

\subsection{Synthesis and Characterization of AMZ}

The natural zeolite used in the study was purchased from Merck, South Africa. The chemical treatment of the zeolite was performed by adding $1 \mathrm{~L}$ of $2 \mathrm{MNH}_{4} \mathrm{Cl}$ solution to $100 \mathrm{~g}$ of zeolite (fraction $2-3 \mathrm{~mm}$ ) at $25^{\circ} \mathrm{C}$. The mixture was shaken for $24 \mathrm{~h}$. The solid phase was separated from the solution, washed until all chloride ions had been removed (checked using $\mathrm{AgNO}_{3}$ solution). The samples were then dried at $105^{\circ} \mathrm{C}$ and stored for further experiments.

Natural and modified zeolites were characterized using X-ray fluorescence (chemical composition, performed in the School of Geosciences at Wits University) and FTIR (Tensor 27, Bruker, Germany) (for the identification of functional groups) while the surface area and cationic exchange capacity (CEC) were determined by the Brunauer-Emmet-Teller (BET surface area and porosity analyzer, (Tristar 3000 Analyzer, Micromeritics, USA) and $\mathrm{BaCl}_{2}$ methods ${ }^{16}$, respectively.

\subsection{Reagents and Standards}

Uranium stock solution of $100 \mathrm{mg} \mathrm{L}^{-1}$ was prepared by dissolving an appropriate amount of uranyl nitrate hexahydrate $\left(\mathrm{UO}_{2}\left(\mathrm{NO}_{3}\right)_{2} \cdot 6 \mathrm{H}_{2} \mathrm{O}\right)$ obtained from Sigma Aldrich. Working solutions were prepared by serial dilution of the stock solution. Other metal ions stock solutions $\left(\mathrm{Fe}^{3+}, \mathrm{Ca}^{2+}, \mathrm{Sr}^{2+}\right.$ and $\left.\mathrm{Mg}^{2+}\right)$ were prepared by dissolving a known mass of metal chloride salt in deionized water and then diluting to the desired concentration.

\subsection{Batch Experiments}

Batch adsorption experiments were carried out by shaking $1 \mathrm{~g}$ of $A M Z$ with $50 \mathrm{~mL}$ of $\mathrm{U}(\mathrm{VI})$ solution at varying experimental conditions in $250 \mathrm{~mL}$ plastic bottles at a speed of $150 \mathrm{rpm}$. When the adsorption equilibrium was reached, the solution was filtered to separate AMZ and the concentration of uranium in the filtrate was determined using ICP-OES (Spectro, Kleve, Germany).

\subsubsection{Effect of Adsorbent Mass ( $0.5 \mathrm{~g}$ to $5 \mathrm{~g}$ )}

Different amount $(0.5,1,2$ and $5 \mathrm{~g})$ of AMZ was added to $50 \mathrm{~mL}$ of $20 \mathrm{mg} \mathrm{L}^{-1}$ of uranium solution. The contents were shaken for $180 \mathrm{~min}$ at room temperature at $150 \mathrm{rpm}$ using an automated SHAKER (Labcon, USA). The remaining uranium concentration in the filtrate was determined.

\subsubsection{Effect of $U(V I)$ Concentration}

Adsorption isotherms were evaluated at different initial concentration of uranium-nitrate solutions, varying from 10 to $50 \mathrm{mg} \mathrm{L}^{-1}$ at $\mathrm{pH} 3$ and $25^{\circ} \mathrm{C}$ while keeping the adsorbent mass $(1$ $\mathrm{g})$ and the solution volume $(50 \mathrm{~mL})$ constant. The mixture was shaken for $180 \mathrm{~min}$ at room temperature. At equilibrium, the solutions were filtered and the equilibrium concentrations of $\mathrm{U}(\mathrm{VI})$ determined.

\subsubsection{Effect of $p H$}

The effect of $\mathrm{pH}$ on the adsorption capacity of uranium onto AMZ was investigated by adding $1 \mathrm{~g}$ of $\mathrm{AMZ}$ to $50 \mathrm{~mL}$ of $20 \mathrm{mg}$ $\mathrm{L}^{-1}$ uranium solution. The $\mathrm{pH}$ was adjusted using $\mathrm{HNO}_{3}$ and $\mathrm{NaOH}$ to obtain the desired $\mathrm{pH}(3-8)$. Then the mixture was shaken for $180 \mathrm{~min}$ at room temperature at $150 \mathrm{rpm}$. The uranium concentration in the filtered supernatant solution was determined.

\subsubsection{Effect of Carbonates and Sulphates}

$0.2 \mathrm{M}$ of $\mathrm{Na}_{2} \mathrm{CO}_{3}$ solution and $20 \mathrm{mg} \mathrm{L}^{-1}$ of uranyl-nitrate solution were mixed in ratios of 4:1 (40 mL: $10 \mathrm{~mL})$ and 1:1 $(25 \mathrm{~mL}$ :
$25 \mathrm{~mL}$ ). Each mixture was added to bottles containing $1.0 \mathrm{~g}$ of AMZ. The contents were then shaken for $180 \mathrm{~min}$ at room temperature. In the same way, $20 \mathrm{mg} \mathrm{L}^{-1}$ of uranyl solution was mixed with different concentrations of $\mathrm{H}_{2} \mathrm{SO}_{4}$ solution $(1 \mathrm{M}$, $0.1 \mathrm{M}$ and $0.01 \mathrm{M}$ ) in the ratios of $4: 1$ and 1:1. The different mixtures were added into bottles containing $1.0 \mathrm{~g}$ AMZ. The contents were then shaken for $180 \mathrm{~min}$ at room temperature at $150 \mathrm{rpm}$.

\subsubsection{Effect of Fe, $\mathrm{Mg}$, Sr and $\mathrm{Ca}$ on U(VI) Adsorption}

The study of competitive adsorption was performed at an initial $\mathrm{pH}$ of 3 at $25^{\circ} \mathrm{C} .20 \mathrm{mg} \mathrm{L}^{-1}$ of uranyl-nitrate solution was mixed with solutions of $\mathrm{FeCl}_{3}, \mathrm{MgCl}_{2}, \mathrm{SrCl}_{2}$ and $\mathrm{CaCl}_{2}$ at different concentrations $(1.0,0.1$ and $0.01 \mathrm{M}$ ) in a ratio of $1: 1$ to make $50.0 \mathrm{~mL}$ solution and the different mixtures were added to bottles containing $1.0 \mathrm{~g}$ of AMZ. The contents were shaken for $180 \mathrm{~min}$ at room temperature.

\subsubsection{Effect of Contact Time}

The effect of contact time was assessed by adding $500 \mathrm{~mL}$ of $20 \mathrm{mg} \mathrm{L}^{-1} \mathrm{U}(\mathrm{VI})$ solution to a 1-L beaker containing $25 \mathrm{~g}$ of AMZ. The mixture was shaken using an automated checker at $150 \mathrm{rpm}$ and the temperature was kept constant at $25^{\circ} \mathrm{C}$ for the study. Samples $(5 \mathrm{~mL})$ were withdrawn at pre-determined time intervals $(30,60,90,120$ and $180 \mathrm{~min})$, the volume drawn being $<10 \%$ of the total volume. This was to minimize the change in the ratio between the metal concentration and the sorbent mass. The change in solution volume with each sampling was taken into account during the calculations. Samples were filtered and analyzed for the residual U(VI) concentration.

\subsubsection{Desorption Studies}

Batch desorption tests to regenerate AMZ from different solutions (U-nitrate, U-sulphate and U-carbonate) were conducted using $50.0 \mathrm{~mL}$ of $0.1 \mathrm{M} \mathrm{Na}_{2} \mathrm{CO}_{3}$. The mixture was agitated in $250 \mathrm{~mL}$ bottles at $150 \mathrm{rpm}$ for $12 \mathrm{~h}$ using a mechanical automated shaker. The concentration of uranium in the filtrate was determined.

\subsection{Data Processing}

The amount of uranium adsorbed onto AMZ was calculated using the mass balance equation expression: ${ }^{14-15}$

$$
q_{e}=\frac{\left(C_{o}-C_{e}\right)}{M}
$$

where $q_{e}\left(\mathrm{mg} \mathrm{g}^{-1}\right)$ is the adsorption capacity; $C_{o}$ and $C_{e}\left(\mathrm{mg} \mathrm{L}^{-1}\right)$ are the initial and equilibrium metal concentrations, respectively; $V$ is the solution volume $(\mathrm{L})$ and $M$ is the amount of adsorbent $(\mathrm{g})$.

The Langmuir and Freundlich models (Equations 2 and 3, respectively), were used to fit the adsorption data. ${ }^{17-19}$

$$
\begin{aligned}
& q_{e}=\frac{q_{m} \cdot b \cdot C_{e}}{1+b \cdot C_{e}} \\
& q_{e}=K_{F} C_{e}^{1 / n}
\end{aligned}
$$

where $q_{m}\left(\mathrm{mg} \mathrm{g}^{-1}\right)$ is the monolayer adsorption capacity and $b$ $\left(\mathrm{L} \mathrm{mg}^{-1}\right)$ is the adsorption equilibrium constant related to the free energy of adsorption. $K_{F}\left(\mathrm{mg}^{1-(1 / n)} \mathrm{L}^{1 / n} \mathrm{~g}^{-1}\right)$ and $n$ are empirical Freundlich constants.

The isotherms were also evaluated using the DubininRadushkevich (DR) model: ${ }^{20}$

$$
\begin{aligned}
& \ln q_{e}=\ln X_{m}+\beta \cdot F^{2} \\
& F=\text { R.T. } \ln \left(1+\frac{1}{C_{e}}\right)
\end{aligned}
$$


where: $X_{m}$ is the maximum sorption capacity of sorbent $\left(\mathrm{mol} \mathrm{g}^{-1}\right)$ and $F$ is the Polanyi potential. $\beta$ is the constant $\left(\mathrm{mol}^{2}(\mathrm{~kJ})^{-2}\right)$ related to mean sorption energy; $R$ is the gas law constant $(\mathrm{kJ}$ $(\mathrm{mol} \mathrm{K})^{-1}$ ) and $T$ the absolute temperature $(\mathrm{K})$.

The free energy change $\left(E_{s}, \mathrm{~kJ} \mathrm{~mol}^{-1}\right)$ required to transfer one mole of ion from infinity in the solution to the solid surface was derived from Equation 6:18

$$
E_{s}=\frac{1}{\sqrt{-2 \cdot \beta}}
$$

The pseudo-second-order kinetic (Equation 7) and intraparticle diffusion rate or Weber Morris (Equation 8) models were applied for the time dependence of adsorption to assess the controlling mechanism of the adsorption process. ${ }^{21}$

$$
\begin{aligned}
\frac{t}{q_{t}} & =\frac{1}{k_{2} q_{e}^{2}} \\
q_{t} & =K_{p} \cdot t^{0.5}+I_{d}
\end{aligned}
$$

where: $q_{t}$ and $q_{e}$ are the adsorbed amounts $\left(\mathrm{mol} \mathrm{kg}^{-1}\right)$ at time $t$ (experimentally obtained) and at equilibrium (obtained from the second-order model), $k_{2}$ and $k_{p}$ are the rate constants, $I_{d}$ is a constant used to examine the relative significance of the two transport mechanisms of the solute, intraparticle diffusion and external mass transfer.

The distribution coefficients $\left(K_{D}\right)$ were derived from $K_{D}=q_{e} / C_{e}$.

A normalized standard deviation $(\Delta q)$ was used in order to compare the validity of each model. $\Delta q(\%)$ is calculated by the following expression: $:^{22}$

$$
\Delta q(\%)=100 \cdot \sqrt{\frac{\sum_{i=1}^{n}\left(\frac{q_{\exp }-q_{c a l}}{q_{\exp }}\right)^{2}}{n-1}}
$$

where: $q_{\exp }$ is the experimental metal ion uptake, $q_{c a l}$ the calculated amount of metal ions adsorbed and $n$ is the number of data points. The goodness-of-fit of the models to the experimental data was determined by comparison of the correlation coefficients $\left(R^{2}\right)$. Speciation of uranium was assessed using MEDUSA software (freeware by KTH, Sweden), ${ }^{23}$ assuming thermodynamic equilibrium.

\section{Results and Discussion}

\subsection{Characteristics of Natural and Modified Zeolites}

The natural zeolite had the following chemical composition:
$\mathrm{SiO}_{2}-77.36 \%, \mathrm{Al}_{2} \mathrm{O}_{3}-12.96 \%, \mathrm{Fe}_{2} \mathrm{O}_{3}-0.13 \%, \mathrm{FeO}-1.08 \%, \mathrm{CaO}$ $-1.42 \%, \mathrm{mgO}-0.92 \%, \mathrm{TiO}_{2}-0.15 \%, \mathrm{Na}_{2} \mathrm{O}-1.62 \%, \mathrm{~K}_{2} \mathrm{O}-4 \%$ and LOI $-11.96 \%$. The high silica content of the natural zeolite makes it more selective for cations with lower charge density (e.g. $\mathrm{NH}_{4}^{+}$) and efficient for the formation of AMZ. The cationic exchange capacity (meq $100 \mathrm{~g}^{-1}$ ) of zeolite and AMZ was 23.16 and 31.65 , respectively.

Figure 1 shows the FT-IR spectra of natural zeolite, Na-zeolite as well as ammonium-modified zeolite (AMZ). The presence of strong peaks of N-H around $3180 \mathrm{~cm}^{-1}$ and $1400 \mathrm{~cm}^{-1}$ for AMZ spectrum was the evidence of the presence of amino groups on the surface of zeolite.

\subsubsection{Effect of AMZ Mass ( $0.5 \mathrm{~g}$ to $5 \mathrm{~g}$ )}

Figure 2 presents the adsorption of uranium on various amounts of AMZ ( $0.5 \mathrm{~g}$ to $2 \mathrm{~g}$ ). The uranium uptake decreases with the increase of $\mathrm{AMZ}$, likely due to the metal shortage in solution as more binding active sites were available for uranium adsorption. As shown in Fig. 2, the maximum uranium uptake was attained with a solid/1iquid ratio of $0.5 \mathrm{~g}: 50 \mathrm{~mL}$.

\subsubsection{Effect of Initial Uranium Concentration}

Uranium removal increased with the increase of initial uranium concentration (U-nitrate) from 10 to $50 \mathrm{mg} \mathrm{L}^{-1}$ at $\mathrm{pH}$ 3. The maximum adsorption capacity was $2.116 \mathrm{mg} \mathrm{g}^{-1}$ with the initial uranium concentration of $50 \mathrm{mg} \mathrm{L}^{-1}$. This increase could be attributed to an increase in the driving force of the concentration gradient rather than an increase in the initial metal ion concentration. Under the same conditions, if the concentration of uranium in the solution is higher, the active sites of the adsorbent are surrounded by more metal ions, making the adsorption process more effective. Therefore, the value of $q_{e}$ increased with increasing initial metal ion concentration.

\subsubsection{Adsorption Isotherms}

The adsorption isotherms represent the relationship between the amounts of solute adsorbed by a unit mass of solid and the amount of solute remaining in the solution at equilibrium.

The parameters determined from the isotherm models, namely Langmuir, Freundlich and DR models are listed in Table 1.

The best correlation coefficient $\left(R^{2}=0.9992\right)$ was obtained with the Langmuir isotherm. The model is based on the assumption that maximum adsorption corresponds to saturated monolayer of uranium(VI) molecules on the adsorbent surface, that the

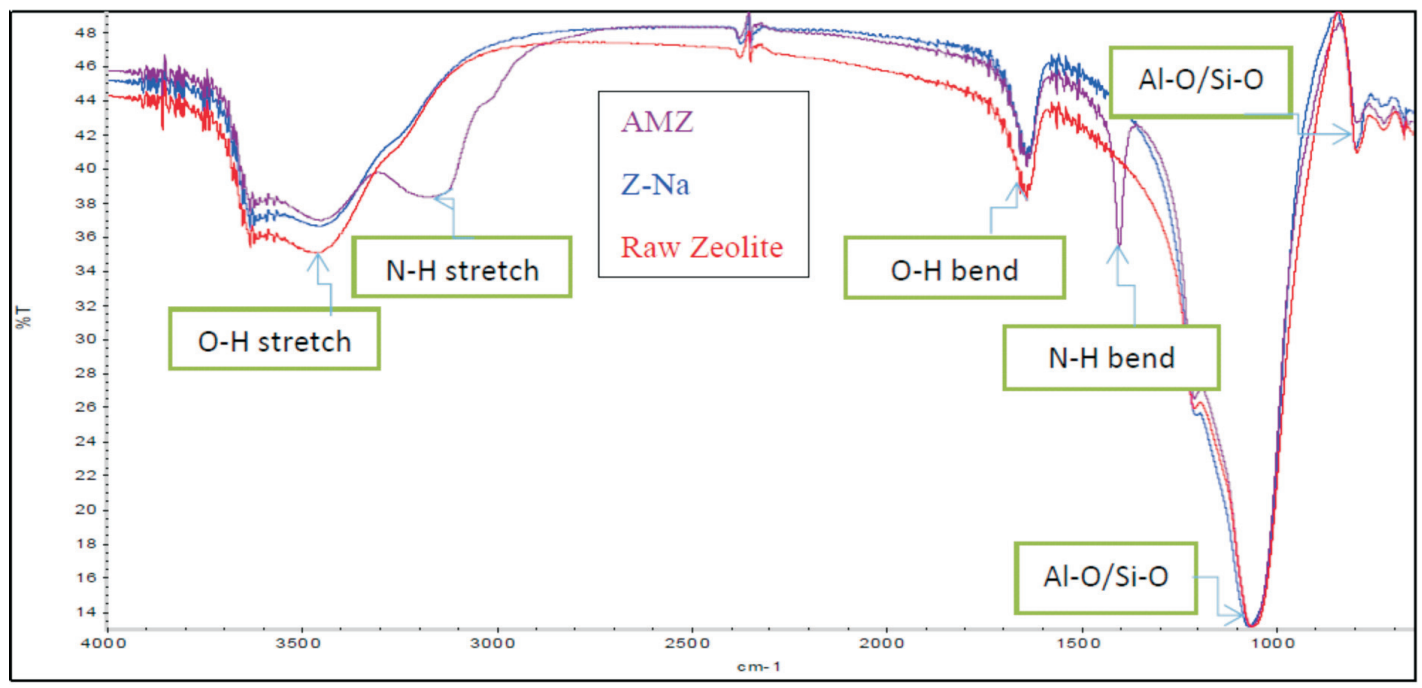

Figure 1 FTIR spectra of natural zeolite (raw zeolite - red), Z-Na (Na-zeolite - blue) and AMZ (purple). 
Table 1 Langmuir, Freundlich and D-R parameters for uranium ion adsorption on AMZ.

\begin{tabular}{ccccccccccccc}
\hline & \multicolumn{3}{c}{ Langmuir } & \multicolumn{1}{c}{ Freundlich } & \multicolumn{4}{c}{ D-R } \\
\hline & $\begin{array}{c}q_{m} \\
/ \mathrm{mg} \mathrm{g}^{-1}\end{array}$ & $\begin{array}{c}b \\
\mathrm{~L} \mathrm{~mol}{ }^{-1}\end{array}$ & $R^{2}$ & $\begin{array}{c}\Delta q \\
/ \%\end{array}$ & $\begin{array}{c}K_{\mathrm{F}} \\
/ \mathrm{mg} \mathrm{g}^{-1}\end{array}$ & $n$ & $R^{2}$ & $\begin{array}{c}\Delta q \\
/ \%\end{array}$ & $\begin{array}{c}X_{m} \\
/ \mathrm{mol} \mathrm{g}^{-1}\end{array}$ & $\begin{array}{c}E_{s} \\
/ \mathrm{kJ} \mathrm{mol}^{-1}\end{array}$ & $\begin{array}{c}R^{2} \\
\Delta q \\
/ \%\end{array}$ \\
\hline $\mathrm{UO}_{2}{ }^{2+}$ & 2.056 & 2217 & 0.9992 & 17.89 & 0.980 & 2.397 & 0.9625 & 32.74 & 0.005 & 10.09 & 0.9772 & 67.22 \\
\hline
\end{tabular}

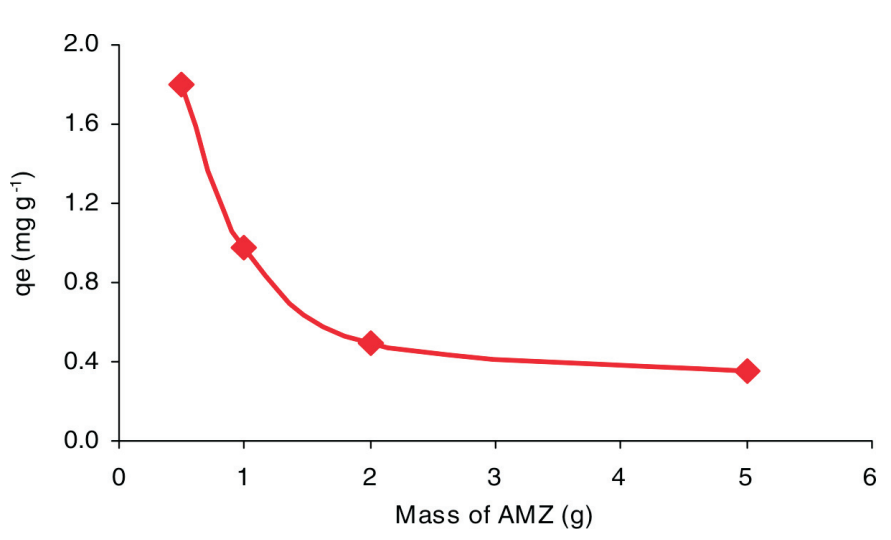

Figure 2 Effect of AMZ mass on the adsorption of uranium (VI) $(n=3$ and RSD $<10 \%$ ).

energy of adsorption is constant and that there is no transmigration of adsorbate on the surface of AMZ..$^{14,24}$

When comparing the statistical results $(\Delta q \%)$ of the three models applied in this work, it would appear that the Langmuir and Freundlich isotherms better predicted the equilibrium of uranium(VI) adsorption onto AMZ in the studied concentration range.

The high value of the Langmuir parameter, $b$, indicated the high affinity of uranium towards AMZ. The experimental adsorption capacity $\left(2.116 \mathrm{mg} \mathrm{g}^{-1}\right)$ was similar to the one obtained from the Langmuir model $\left(2.056 \mathrm{mg} \mathrm{g}^{-1}\right)$. The Freundlich constant $\left(K_{F}\right)$ was 0.98 and the subunitary value of ratio $1 / n$ suggests that the adsorption was favourable.

The experimental equilibrium data of uranium (VI) were also compared with the theoretical equilibrium data obtained from these adsorption models. The plots (not shown in this paper) confirmed that the adsorption equilibrium data fitted well to the Langmuir model in the studied conditions. The isotherm was found to be linear over the entire concentration range studied. The Dubinin-Radushkevich isotherm model provides information about the physical or chemical character of biosorption process.

The adsorption energy $\left(E_{s}\right)$ value obtained for the experiment data was $10.09 \mathrm{~kJ} \mathrm{~mol}^{-1}$, depicting an ion exchange mechanism. ${ }^{25}$

\subsubsection{Effect of $p H$}

The solution $\mathrm{pH}$ affects the solubility and speciation of uranium in solution as well as the overall charge of the sorbent. The removal of uranium by AMZ was studied in the $\mathrm{pH}$ range between 3 and 8 and the results are presented in Fig. 3 .

The adsorption of uranium was observed to be strongly dependent on the solution $\mathrm{pH}$. A high uptake was observed under acidic conditions ( $\mathrm{pH} 3-5)$ with a maximum adsorption obtained at $\mathrm{pH} 5$. As $\mathrm{pH}$ increased from 5 to 8 , the fraction of $\mathrm{U}(\mathrm{VI})$ adsorbed decreased.

At $\mathrm{pH}$ between 3 and 5, various monomeric and polymeric hydrolyzed species of $\mathrm{UO}_{2}^{2+}$ are formed (Fig. 4a). These include: $\mathrm{UO}_{2}{ }^{2+},\left(\mathrm{UO}_{2}\right) \mathrm{OH}^{+},\left(\mathrm{UO}_{2}\right)_{2}(\mathrm{OH})_{2}{ }^{2+},\left(\mathrm{UO}_{2}\right)(\mathrm{OH})_{5}{ }^{+}$, among others.

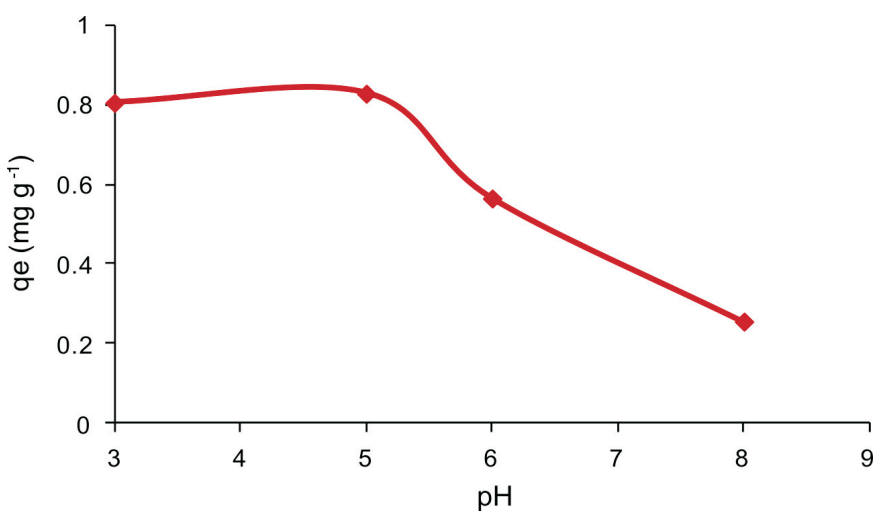

Figure 3 Effect of $\mathrm{pH}$ on adsorption of $\mathrm{UO}_{2}{ }^{2+}$ from aqueous solution by $\mathrm{AMZ}\left(\right.$ temp $=25^{\circ} \mathrm{C}$, conc $=20 \mathrm{mg} \mathrm{L}^{-1}$, contact time $\left.=3 \mathrm{~h}\right)(n=3$ and RSD $<10 \%$ ).

At $\mathrm{pH} 5, \mathrm{UO}_{2}(\mathrm{OH})_{2} \cdot \mathrm{H}_{2} \mathrm{O}(\mathrm{c})$ is the main species, indicating that the removal of uranium could be a combination of adsorption and precipitation. The decrease in the uptake of uranium at $\mathrm{pH}>5$ could be attributed to the formation of negatively charged soluble uranium complexes with lower adsorption affinities, i.e. $\mathrm{UO}_{2}(\mathrm{OH})_{3}^{-}, \mathrm{UO}_{2}(\mathrm{OH})_{4}{ }^{2-},\left(\mathrm{UO}_{2}\right)_{3}(\mathrm{OH})_{7}{ }_{7}^{-}$. The neutral or anionic species depend on the hydroxide groups bonded to the uranium and thus decreasing the possibility of being adsorbed by the AMZ since the electrostatic force between the uranium complexes and AMZ is negligible. ${ }^{26}$

A similar trend was obtained by Sert and Eral $^{27}$ as well as Bachmaf and Merkel $^{28}$ when using aminopropyl-modified mesoporous sorbent and clay minerals for the adsorption of uranium, respectively.

3.2.5. Effect of Carbonates and Sulphates on the Adsorption of U(VI) The effect of the presence of carbonates and sulfates on the removal of uranium by AMZ was studied as these ions are usually present in water-system. The results of the adsorption capacity and the distribution coefficient are given in Table 2 .

As shown in Table 2, both carbonates and sulphates reduced U(VI) uptake to $67.88 \%$ and $71.63 \%$, respectively. Experiments were run at different concentration ratios (carbonate/sulphate: uranium), the ratio $1: 1$ gave the optimum results for both sulphate and carbonate solutions. The presence of carbonates in the solution changes totally the uranium speciation. As shown in Fig. 4b, carbonate is an important ligand in uranyl speciation, particularly at high $\mathrm{pH}$ values, where $\mathrm{UO}_{2}\left(\mathrm{CO}_{3}\right)_{2}{ }^{2-}$ and $\mathrm{UO}_{2}\left(\mathrm{CO}_{3}\right)_{3}{ }^{4-} \mathrm{com}-$ plexes tend to dominate.

At $\mathrm{pH}>5$, the adsorption of $\mathrm{U}(\mathrm{VI})$ onto $\mathrm{AMZ}$ decreased sharply in the presence of carbonate, probably due to the formation of negatively-charged complexes such as $\mathrm{UO}_{2}(\mathrm{OH})_{3}^{-}$, $\mathrm{UO}_{2}(\mathrm{OH})\left(\mathrm{CO}_{3}\right)^{-}$which could be repelled by the negative adsorbent surface. ${ }^{29}$

These results are in agreement with those reported on $\mathrm{U}(\mathrm{VI})$ sorption onto montmorillonite ${ }^{29-30}$ and hydrous silicon dioxide. ${ }^{31}$ The authors observed that under alkaline conditions, sorption was inhibited due to the formation of nega- 


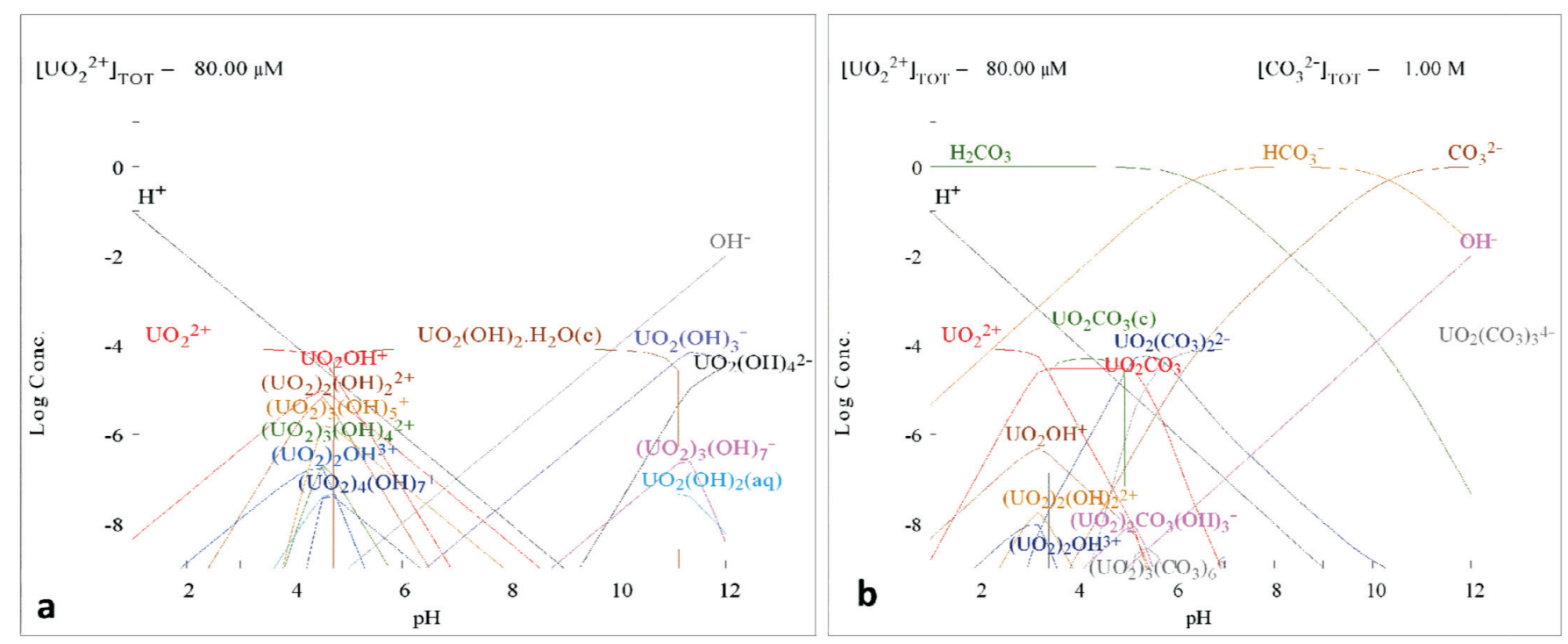

Figure 4 Speciation of uranium in a uranium-water system at $25^{\circ} \mathrm{C}$ and $\mathrm{I}=0 \mathrm{M}(\mathbf{a})$, and in the presence of carbonates (b), calculated using Hydra and Medusa speciation modelling free ware versions.

Table 2 Adsorption capacity of U-nitrate, U-sulphate and U-carbonate complexes on AMZ.

\begin{tabular}{llcc}
\hline U-solution & Concentration/Ratios & $q_{e} / \mathrm{mg} \mathrm{g}^{-1}$ & $K_{\mathrm{D}} / \mathrm{L} \mathrm{g}^{-1}$ \\
\hline U-nitrate & & 0.825 & 1.116 \\
\hline U-sulphate & $0.01 \mathrm{M}-4: 1$ & 0.258 & 0.029 \\
& $1: 1$ & 0.314 & \\
& $0.1 \mathrm{M}-4: 1$ & 0.079 & \\
& $1: 1$ & 0.265 & \\
& $1 \mathrm{M}-4: 1$ & 0.061 & \\
& $1: 1$ & 0.263 & 0.019 \\
\hline U-carbonate & $0.2 \mathrm{M}-4: 1$ & 0.034 & \\
& $1: 1$ & 0.234 & \\
\hline
\end{tabular}

tively charged U(VI)-carbonate complexes. ${ }^{30-32}$

In the presence of sulphate ions, uranium complexes such as $\mathrm{UO}_{2}\left(\mathrm{SO}_{4}\right)_{2}{ }^{2-}$ and $\mathrm{UO}_{2} \mathrm{SO}_{4}$ are formed in the acidic region, with a small fraction of $\mathrm{UO}_{2} \mathrm{OH}^{+}$and $\left(\mathrm{UO}_{2}\right)_{3}(\mathrm{OH})_{5}{ }^{+}$also present.

The U-sulphate complexes would typically form in acidic mine leachates. The results reported here support the observation of Bachmaf et al. ${ }^{12}$ who concluded that the presence of sulphate substantially decreased U(VI) uptake by montmorillonite. Similarly, findings by Venkataramani and Gupta showed that a strong complexing ligand such as $\mathrm{SO}_{4}^{2-}$ could substantially decrease $\mathrm{U}(\mathrm{VI})$ sorption on hydrous oxides at low $\mathrm{pH}$, either by forming uranyl-sulfate complexes or by competing for available sites. $^{33}$

The distribution coefficient $\left(K_{D}\right)$ was higher for U-nitrate $\left(1.116 \mathrm{~L} \mathrm{~g}^{-1}\right)$ indicating the high affinity and selectivity towards the sorbent (AMZ). The affinity of uranium complexes towards $\mathrm{AMZ}$ is in the following sequence:

uranium-nitrate $>$ uranium-sulphate $>$ uranium-carbonate.

\subsubsection{Effect of $\mathrm{Ca}^{2+}, \mathrm{Mg}^{2+}, \mathrm{Sr}^{2+}$ and $\mathrm{Fe}^{3+}$ on Uranium Adsorption}

It is important to assess the effect of competing cations in the study of uranium adsorption. The results of the uptake of uranium in the presence of $\mathrm{Ca}^{2+}, \mathrm{Mg}^{2+}$ and $\mathrm{Sr}^{2+}$ are shown in Fig. 5.

The presence of $\mathrm{Ca}^{2+}, \mathrm{Mg}^{2+}$ and $\mathrm{Sr}^{2+}$ resulted in a decrease of uranium (U-nitrate system) uptake by AMZ. A significant reduction was observed even at relatively low concentrations $(0.1 \mathrm{M})$ of these ions. The amount of uranium adsorbed was reduced to $19.57 \%, 31.60 \%$ and $23.65 \%$ in the presence of $\mathrm{Ca}^{2+}, \mathrm{Mg}^{2+}$ and $\mathrm{Sr}^{2+}$, respectively. This trend could be attributed to the competitive effect between uranium(VI) and cations for the binding sites available for the adsorption process. Another factor could be the formation of negatively charged Sr-, Caand $\mathrm{Mg}$-uranium complexes. ${ }^{34}$

This is a phenomenon of importance in geochemical modelling of uranium transport in aquifers as the presence of calcite $\left(\mathrm{CaCO}_{3}\right)$ has been found to reduce adsorption of uranium significantly, resulting in pollution of down gradient boreholes.

A different trend was observed when $\mathrm{Fe}^{3+}$ was added to uranium solutions as seen in Table 3. The results show an increase of $20 \%, 72 \%$ and $82 \%$ for U-nitrate, U-carbonate and U-sulphate, respectively. This increase might be described by two processes, namely: the formation of complexes between $\mathrm{Fe}^{3+}$ and $\mathrm{NO}_{3}^{-}, \mathrm{CO}_{3}^{2-}, \mathrm{SO}_{4}^{2-}$, thus releasing uranium from these complexes which in turn is adsorbed on AMZ; or the binding of uranium complexes to $\mathrm{Fe}^{3+}$ as well as onto $\mathrm{AMZ}$, a situation resembling a salt bridge set up (surface-uranium complex-Feuranium complex). Further investigation into these processes would be required.

Table 3 Effect of $\mathrm{Fe}^{3+}$ on adsorption of different uranium complexes.

\begin{tabular}{lccc}
\hline Solution & Ratio & $q_{e} / \mathrm{mg} \mathrm{g}^{-1}$ & $\%$ Increase \\
\hline U-nitrate & & 0.825 & \\
U-nitrate + 0.1 M Fe $\left(\mathrm{NO}_{3}\right)$ & $(1: 1)$ & 0.991 & 20.18 \\
U-sulphate & & 0.265 & \\
U-sulphate + 0.1 M Fe $\left(\mathrm{NO}_{3}\right)_{3}$ & $(1: 1)$ & 0.458 & 72.48 \\
U-carbonate & & 0.234 & \\
U-carbonate + 0.1 M Fe $\left(\mathrm{NO}_{3}\right)_{3}$ & $(1: 1)$ & 0.400 & 82.43 \\
\hline
\end{tabular}

\subsubsection{Effect of Contact Time}

In order to determine the equilibrium time for uranium (VI) adsorption on AMZ, the kinetics of the adsorption was investigated. The kinetic sorption was characterized by a rapid initial uptake followed by a slower rate of uptake. After $30 \mathrm{~min}$ of contact, more than $90 \%$ of uranium had been adsorbed. In addition, no systematic decrease in adsorption percentage 


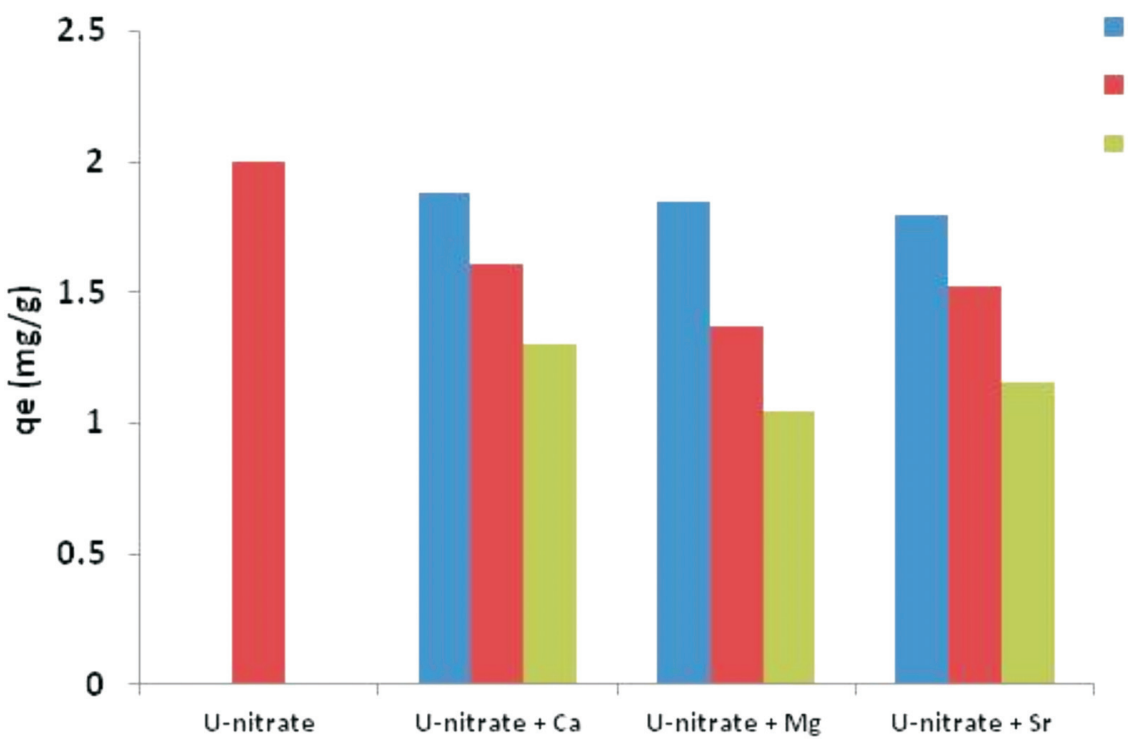

Figure 5 Effect of $\mathrm{Ca}^{2+}, \mathrm{Mg}^{2+}$ and $\mathrm{Sr}^{2+}$ on the adsorption of uranium (VI) (U- nitrate system $(n=3$ and $\mathrm{RSD}<10 \%$ ).

of U(VI) was observed after that. In the first phase, AMZ sites for adsorption were vacant and the concentration gradient of uranium was high. ${ }^{35}$ During the second phase, the adsorption rate was controlled by intraparticle diffusion until the metal uptake reaches equilibrium. ${ }^{24}$ The kinetic study gives an indication of the time at which the material will be highly effective for scale up purpose.

\subsubsection{Kinetic Models}

With respect to the kinetic modelling of uranium adsorption on AMZ, the pseudo-second-order and intraparticle diffusion models were used to fit the experimental data. The results presented in Table 4 showed that the pseudo-second-order model gave the best fit for the adsorption of U-nitrate and U-sulphate with $R^{2}>0.980$, implying that the rate controlling mechanism is a chemical process. ${ }^{36}$

The values of adsorbed amounts at equilibrium obtained from the model $\left(q_{\text {ecalc }}\right)$ are close to those obtained from the experiment $\left(q_{\text {eexp }}\right)$. These results confirmed that the nature of adsorption was concentration-dependent, confirming that the ratecontrolling step was chemical sorption. The rate constant $\left(k_{2}\right)$ was lower for U-carbonate complex as its adsorption was likely intraparticle diffusion. The values of the constant $I_{d}$ were in the range $0.014-0.041$, the close values of $I_{d}$ prove that the intraparticle diffusion is the determining step and not the diffusion. ${ }^{21}$

\subsubsection{Desorption Studies}

The adsorbed uranium from U-nitrate, U-sulphate and U-carbonate was desorbed using $0.1 \mathrm{M}$ of $\mathrm{Na}_{2} \mathrm{CO}_{3}$ solution. The results presented in Fig. 6 reveal the high desorption percentage for U-carbonate. This result confirms the low affinity or weak adsorption of U-carbonate complex towards AMZ as substantiated by the low distribution coefficient obtained for U-carbonate complex (Table 2). U- nitrate was the less desorbed, implying that it has higher affinity towards AMZ as revealed by the $K_{D}$ value. Further desorption study could be done using nitric and sulphuric acids.

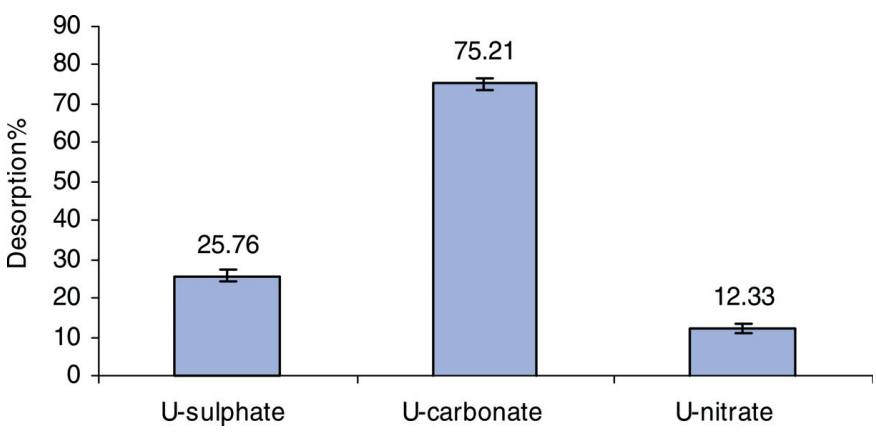

Figure 6 Desorption percentage of U-nitrate, U- sulphate and U-carbonate adsorbed on AMZ $(n=3$ and RSD $<10 \%)$.

\section{Conclusion}

This research demonstrates that AMZ is effective for the removal of uranium(VI) from aqueous solutions dominated by nitrates, carbonates and sulphates using a solid:liquid ratio of 1:100. The effectiveness of the adsorption from the three uranium solutions followed the sequence of: U-nitrate $(0.825 \mathrm{mg}$ $\left.\mathrm{g}^{-1}\right)>$ U-sulphate $\left(0.265 \mathrm{mg} \mathrm{g}^{-1}\right)>$ U-carbonate $\left(0.234 \mathrm{mg} \mathrm{g}^{-1}\right)$.

The removal of uranium was optimum under acidic conditions $(\mathrm{pH}<5)$. The presence of carbonates reduced the adsorption

Table 4 Kinetic parameters of the adsorption of uranium onto AMZ.

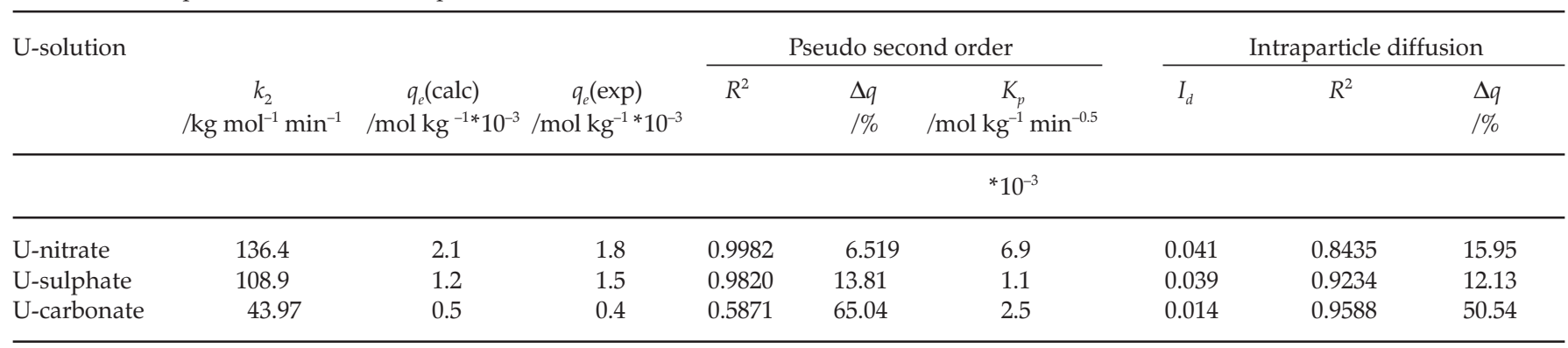


of $\mathrm{U}(\mathrm{VI})$, largely due to the formation of negatively charged uranyl-carbonate complexes.

The adsorption of uranium onto AMZ for the U-nitrate system was described by the Langmuir isotherm. The presence of $\mathrm{Ca}, \mathrm{Sr}$ and $\mathrm{Mg}$ ions led to the decrease of the adsorption of uranium (an average drop of $24.94 \%$ ) due to competition for binding sites. The presence of $\mathrm{Fe}^{3+}$ in polluted acidic water enhanced the removal of uranium in situ using AMZ. An increase of up to $82.43 \%$ was observed for the U-carbonate system.

The adsorption of uranium from U-nitrate and U-sulphate systems followed the pseudo-second-order kinetic, whilst the intraparticle diffusion described the adsorption for U-carbonate system. Uranium loaded in the AMZ can potentially be desorbed (between $12.33 \%$ and $75.21 \%$ ) in order to regenerate the sorbent for further re-use. As such, AMZ are promising materials for the removal of uranium(VI) from contaminated soils and water systems in acidic environments.

\section{Acknowledgements}

The authors would like to thank the University of the Witwatersrand (through the University Research Committee Postdoc Fellowship) and the National Research Foundation (through THRIP) for financial support.

\section{References}

1 B. Cairncross and R. Dixon, Minerals of South Africa, Geological Society of South Africa, 1995.

2 N.F. Mphephu, Rehabilitation of Tailings on the Central Rand, Ph.D. thesis, University of the Witwatersrand, Johannesburg, South Africa, 2004.

3 F. Winde and L.A. Sandham, Uranium pollution of South African streams - An overview of the situation in gold mining areas of the Witwatersrand, GeoJournal, 2004, 61, 131-149.

4 M. Gavrilescu, L.V. Pavel and I. Cretescu, Characterization and remediation of soils contaminated with uranium, J. Hazard. Mater., 2009, 163, 475-510.

5 M. Mkandawire, B. Taubert and E.G. Dudel, Capacity of Lemna gibba L. (duckweed) for uranium and arsenic phytoremediation in mine tailings waters, Int. J. Phytoremediat., 2004, 6, 347-362.

6 C.C. Choy, G.P. Korfiatis and X.M. Hoboken, Removal of depleted uranium from contaminated soils, J. Hazard. Mater., 2005, 136, 53-60.

7 C. Blanche, Acid Mine Drainage AMD. Available from: http://www. environment.co.za/acid-minedrainage-amd/toxic-water-thewonderfonteinspruit-catchment-area.html, accessed 15 June 2012.

8 World Health Organization (WHO), Guidelines for Drinking-Water Quality, 2004.

9 SABS: South African National Standard (SANS) 241-1: 2011 for Drinking Water. Part 1: Microbiological, Physical and Chemical Determinants. South African Bureau of Standards, Pretoria, South Africa.

10 M. Kinze, Uranium in the aquatic environment, in Proceedings of the International Conference Uranium Mining and Hydrogeology III and the International Mine Water Association Symposium, 2002, Freiberg, Berlin, Germany.

11 I. Grenthe, J. Fuger, R.J.M. Konings, R.J. Lemire, A.B. Muller, C. Nguyen-Trung and H. Wanner, Chemical Thermodynamics of Uranium, (H. Wanner, I. Forrest, eds.), NEA OECD, Issy-les-Moulineaux, France, 1992.

12 S. Bachmaf, P. Friedrich and B.J. Merkel, Effect of sulfate, carbonate, and phosphate on the uranium(VI) sorption behavior onto bentonite, Radiochim. Acta, 2008, 96, 359-366.

13 S. Babel and T.A. Kurniawan, Low-cost adsorbents for heavy metals uptake from contaminated water: a review. J. Hazard. Mater., 2003, 97 219-243.

14 C.J. Chisholm-Brause, J.M. Berg, R.A. Matzner and D.E.Morris, Uranium(VI) sorption complexes on montmorillonite as a function of solution chemistry, J. Colloid Interface Sci., 2001, 233, 38-49.
15 V.K. Gupta and I. Ali, Removal of lead and chromium from wastewater using bagasse fly ash - a sugar industry waste, J. Colloid Interface Sci., 2004, 271, 321-328.

16 G.P. Gillman and E.A. Sumpter, Modification to the compulsive exchange method for measuring exchange characteristics of soils. Aust. J. Soil Res., 1986, 24, 61-66.

17 Q. Hamdaoui and E. Naffrechoux, Modeling of adsorption isotherms of phenol and chlorophenols unto granular activated carbon. Part 1: Two parameter models and equations allowing determination of thermodynamic parameters, J. Hazard. Mater., 2007, 147, 381-394.

18 X.S. Wang, J. Huang, H. Q. Hu, J. Wang and Q. Yong Qin, Determination of kinetic and equilibrium parameters of the batch adsorption of $\mathrm{Ni}(\mathrm{II})$ from aqueous solutions by Na-mordenite, J. Hazard. Mater., 2007, 142, 468-476.

19 V.J. Inglezakis, M.A. Stylianou, D. Gkantzou and M.D. Loizidou, Removal of $\mathrm{Pb}(\mathrm{II})$ from aqueous solutions by using clinoptilolite and bentonite as adsorbents, Desalin., 2007, 210, 248-256.

20 A. Gunaya, E. Arslankaya and I. Tosun, Lead removal from aqueous solution by natural and pretreated clinoptilolite: adsorption equilibrium and kinetics, J. Hazard. Mater., 2007, 146, 362-371.

21 R. Apiratikul and P. Pavasant, Sorption of $\mathrm{Cu}^{2+}, \mathrm{Cd}^{2+}$, and $\mathrm{Pb}^{2+}$ using modified zeolite from coal fly ash, Chem. Eng. J., 2008, 144, 245-258.

22 M.L. Cozmuta, M.A. Cozmuta, A. Peter, C. Nicula, E.N. Bakatula and $\mathrm{H}$. Tutu, The influence of $\mathrm{pH}$ on the adsorption of lead by Na-clinoptilolite: kinetic and equilibrium studies, Water SA, 2012, 38, 269-278.

23 MEDUSA software. Available from: https://www.kth.se/en/che/ medusa/downloads-1.386254, accessed 27 August 2014.

24 I. Langmuir, The constitution and fundamental properties of solids and liquids. Part I. Solids, J. Am. Chem. Soc., 1916, 38, pp. 2221-2295.

25 M.E. Argun, S. Dursun, C. Ozdemir, C and M. Karatas, Heavy metal adsorption by modified oak sawdust: thermodynamics and kinetics, J. Hazard. Mater., 2007, 141, 77-85.

26 W.H. Zou, R.P. Han, Y. Wang and L. Zhu, Removal of uranium(VI) from aqueous solutions by manganese oxide coated zeolite: discussion of adsorption isotherms and pH effect, J. Environ. Radioactiv., 2007, 93, $127-143$.

27 Ş. Sert and M. Eral, Uranium adsorption studies on aminopropyl modified mesoporous sorbent $\left(\mathrm{NH}_{2} \mathrm{MCM} 41\right)$ using statistical design method, J. Nucl. Mater., 2010, 406, 285-292.

28 S. Bachmaf and B.J. Merkel, Determination and interpretation of environmental water samples contaminated by uranium mining activities, Environ. Earth Sci., 2011, 63, 925- 934.

29 H. Tutu, T.S. McCarthy, E.M. Cukrowska, L. Chimuka, L. and R. Hart, Radioactive disequilibrium and geochemical modelling as evidence of uranium leaching from gold tailings dumps in the Witwatersrand Basin, Int. J. Environ. Anal. Chem., 2009, 89, 687-703.

30 R.T. Pabalan, D.R. Turner, F.P. Bertetti, J.D. Prikryl, in Adsorption of Metals by Geomedia, (E.A. Jenne, ed.), Academic Press, San Diego, 1998, pp. 99-130.

31 J.G. Catalano and G.E. Brown, Uranyl adsorption on montmorillonite: evaluation of binding sites and carbonate complexation, Geochim. Cosmochim. Acta, 2005, 69, 2995-3005.

32 K.H. Lieser, S. Quandtklenk and B. Thybusch, Sorption of uranylions on hydrous silicon dioxide, Radiochim. Acta, 1992, 57, 45-50.

33 B. Venkataramani and A.R. Gupta, Effect of anions on the sorption of uranyl ions on hydrous oxides: application of the surface hydrolysis model, Colloid Surf., 1991, 53, 1-19.

34 R.H. Johnson and H. Tutu, Reactive transport modelling at uranium in situ recovery sites: uncertainties in uranium sorption on iron hydroxides. International Mine Water Association Symposium, 2013, Colorado, USA, pp. 377-382.

35 Azouaou, M. Belmedani, H. Mokaddem and Z. Sadaoui, Adsorption of lead from aqueous solution onto untreated orange barks, Chem. Engin. Trans., 2013, 32, 55-60.

36 E.N. Bakatula, Biofunctionalisation and Influence on Remediation capacity of Bentonite and Zeolite for Metal Remediation in Gold Mine and Tailing Water, Ph.D. thesis, University of the Witwatersrand, Johannesburg, South Africa, 2012. 